\title{
WHERE THE KASBAH MET THE HUT: RIVER TAGUS AND THE ENCOUNTER BETWEEN ISLAMIC AND EUROPEAN BUILDING TECHNOLOGIES
}

\author{
ADELAIDA DEL PUERTO GARCÍA \\ Escuela Técnica Superior de Arquitectura de Madrid, UPM \& \\ Colegio Oficial de Arquitectos de Castilla la Mancha, Spain.
}

\begin{abstract}
The aim of this paper is to highlight the importance of the river Tagus as the place of the most occidental encounter between Islamic and European traditional construction technologies. The research stems from a study of Vernacular Architecture in Toledo. The investigation process has included a first phase of field work followed by Archives research, once the case studies have been determined. Further literature review about border typologies has evidenced the links among history, landscape transformations and building technologies.

Vernacular types of architecture in the Mediterranean fringe are usually studied as a whole. It is a vast area of very similar architectural solutions that seem to be born directly from the soil, the climate and cultures coming from the Middle East and northern Africa. But a closer look at this particular territory will reveal how traditional Mediterranean architecture is the result of the merging of two very different ways of understanding the built space, the relationship with the environment and the construction techniques.

The Kasbah architecture, introduced by Islamic culture and based on a lack of interest of interacting with tough environmental surroundings, meets the European style of integrating hut architecture with the landscape. Landscapes of cattle pastures meet olive groves, vineyards and wheat fields. The patio meets the front yard. Very interestingly mixed wall designs emerge from this convergence of the two cultures, but there are also some difficulties when constructing wooden frames and trusses, particularly in the southern areas.

This article delves into the relationship among history, environment and mutations in architecture, focusing on the middle course of the river Tagus.
\end{abstract}

Keywords: Islamic, rammed earth, Tagus, vernacular architecture, wooden structures.

\section{INTRODUCTION}

The footprint of the Islamic conquest in the southern half of the Spanish peninsula mixes Islamic and Berber building technologies. The origin of the conquest was Islamic, but an important amount of Berber population was in charge of repopulating the conquered lands [1]. The Spanish re-conquest timing determined how long the Islamic and Berber presence lasted in the different areas. In the north of the peninsula, the presence was shorter and so was the influence on the different aspects of culture, including architecture. The South and the East coasts of Spain, known as Al-Andalus, were the fringes of territory where the influence lasted for many centuries. In the present, architectural contrasts between the north and the south are still very visible. The landscape, urban fabrics and traditional architecture evolutions are very different. International studies regarding traditional architecture settle the occidental border between European-influenced and Islamic-influenced vernacular architecture in the centre of the peninsula [2,3]. This research contributes to highlight the presence of a natural place for the mixture between both architectural cultures: the river Tagus depression. 


\section{ISLAMIC BORDERS IN THE MIDDLE AGES AND NATURAL ENVIRONMENTS IN WESTERN EUROPE AND NORTHERN AFRICA}

Spain and Portugal are located on the fringes of territory between the great European rivers depressions and the North African Sahara desert. The size and the length of rivers decrease as we descend from France to the north of Morocco (Fig. 1).

The presence of abundant mountain ranges in the peninsula and western Morocco determine the appearance of watercourses. In the peninsula, river Tagus lies in the middle, right between the northern and southern plateaus.

\section{THE TAGUS IN THE CHRONOLOGY OF CHRISTIAN CONQUEST}

River Tagus, in its middle course, lies between two mountain ranges: Montes de Toledo range: $1.220 \mathrm{~m}$. altitude and Gredos range: $2.592 \mathrm{~m}$. In terms of territorial conquest, the north border of the Tagus is an important physical barrier. So are the Central and Iberian ranges, in the north-east and in the upper reaches of the river. The ranges allowed stabilizing the south conquest once it had been gained. From the 8th century until the 12th century, territories at the south of these ranges were part of the Islamic world. The Tagus remained close to the border and was influenced by both cultures: the European and the Islamic. Islamic influence

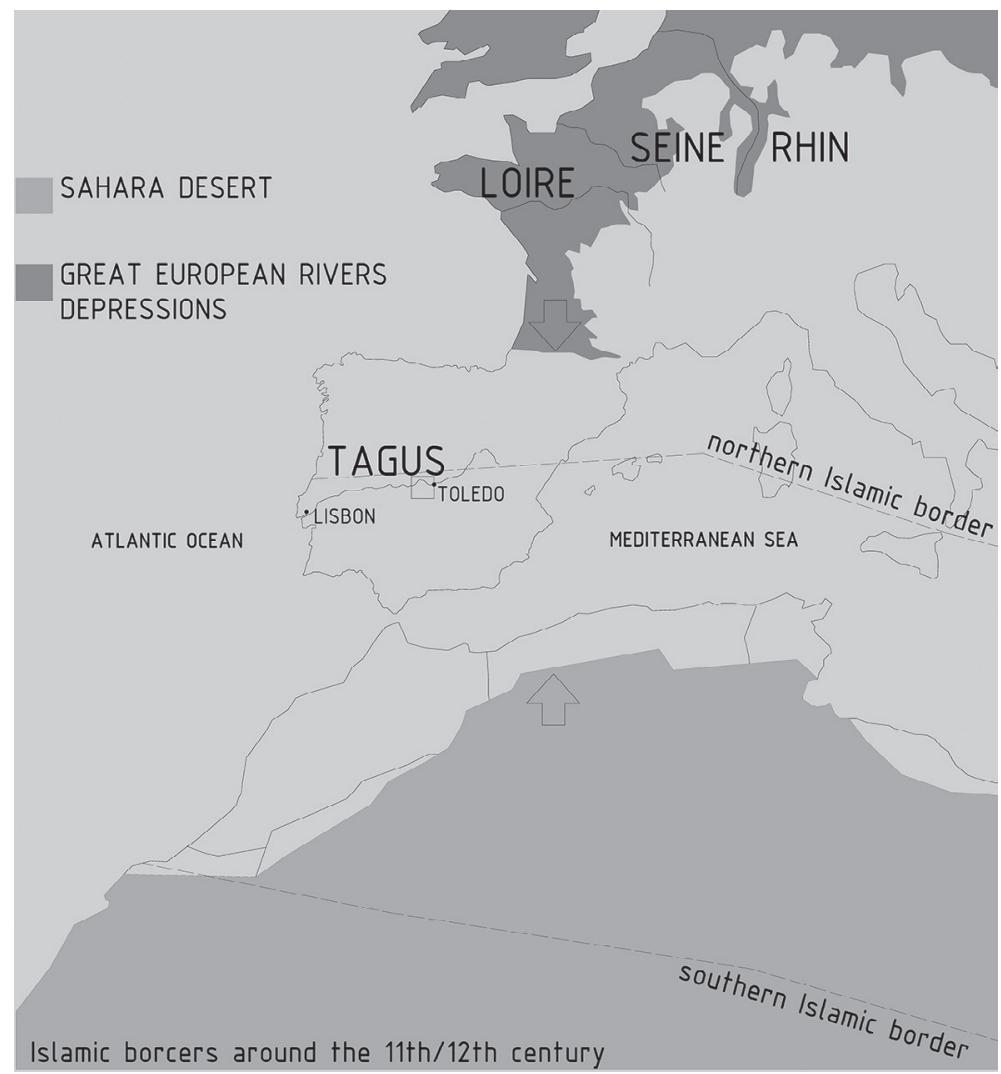

Figure 1: Map of Islamic borders between the 11th and the 12th centuries and natural contrasts between western Europe and northern Africa. Source: the author. Based on [2] and [4]. 
was coming through the north of Africa. Four centuries of cultural immersion and the massive arrival of Berbers to provinces like Toledo [1] strongly influenced the urban fabrics, the use of land and the architecture.

\section{KASBAH BUILDING TECHNIQUES AND ITS INTERACTION WITH NATURE}

Desert and semi-desert territories allow us scarcely to obtain raw materials for construction. Stone is removed by erosion and the lack of rains hinders the appearance of botanical species. Wood has to be used only when it is absolutely necessary $[5,6]$. So is the case with flat roof structures made of thin trunks. Bearing walls are in all cases except the patio, with the vertical structure. Beams are a luxurious option and they are only used when a wider space or an angle appears, helping to change the joist's direction [7]. Bearing walls have a double function: structural and climatic. Bearing walls are made of rammed earth and are protected by mud or lime [8], depending on the economic development. Their thickness helps reduce the absorption of high temperatures into the dwelling.

Interior spaces are arranged around a patio. The patio works as a space distributor and as a natural cooling system. Dwellings share external bearing walls, and they usually have no more than one external facade [9]. Contact with the exterior spaces is scarce and no contact with the surrounding natural environment exists. The house is only perceptible from the inside and there is no aesthetic relationship with the landscape. Vegetation, if any, remains in the patio. Design concentrations are in the patio, which is the core of human recreations $[1,7]$, compensating the lack of natural liveable spaces.

A small number of roads connects the compact urban fabric with the surroundings. Only the Kasbah, as a whole, has facades.

\section{HUT-BUILDING TECHNIQUES AND ITS INTERACTION WITH NATURE}

The wooden hut, which turned into the palafitte type in some European countries during the prehistoric period $[4,10]$, represents the antithesis of the Kasbah, and is a frequent architectural solution in many areas of central and northern Europe. This is the case in some areas of Spain and Portugal too [5].

Hilly territories and great river depressions usually have a common factor: a certain level of humidity that allows botanical species to grow and expand profusely. The abundance of woody species, and the exposure to cold temperatures in winter, determines the use of wood as the main material. It is used as a structure element and also for coating and roofing purposes, due to its good thermal insulation performance. The hut, also known as cabin, is a compact building with no interior open spaces and is covered, in general, with two slopes. Roof structures may vary from cruck to trusses or joists solutions [4, 11].

The hut is inserted, individually, in a generous landscape. As a result, all facades are exterior and the visual exchange with the landscape is mutual: you can see the outside from the inside and the hut is a perceptible element of the landscape, a milestone. Design concentrates on the facades and the roof. The access, the lanes, the orchards and the prairies that surround it determine a low demand of interior space for human recreation. As exterior spaces are liveable, the interior space loses intensity if we compare it with the Kasbah. Only the home fire space requires special attention, and it is an important element in the case of mountain huts.

\section{BUILDING TECHNOLOGIES ON THE SOUTH SIDE OF RIVER TAGUS}

In semi-desert and the desert areas of northern Africa, built volumes that surround the patio are covered with flat roofs. Their geometry changes into one or two slopes, keeping in some cases anti-climatic solutions [12], as we ascend to the Middle Atlas Range. The southern 


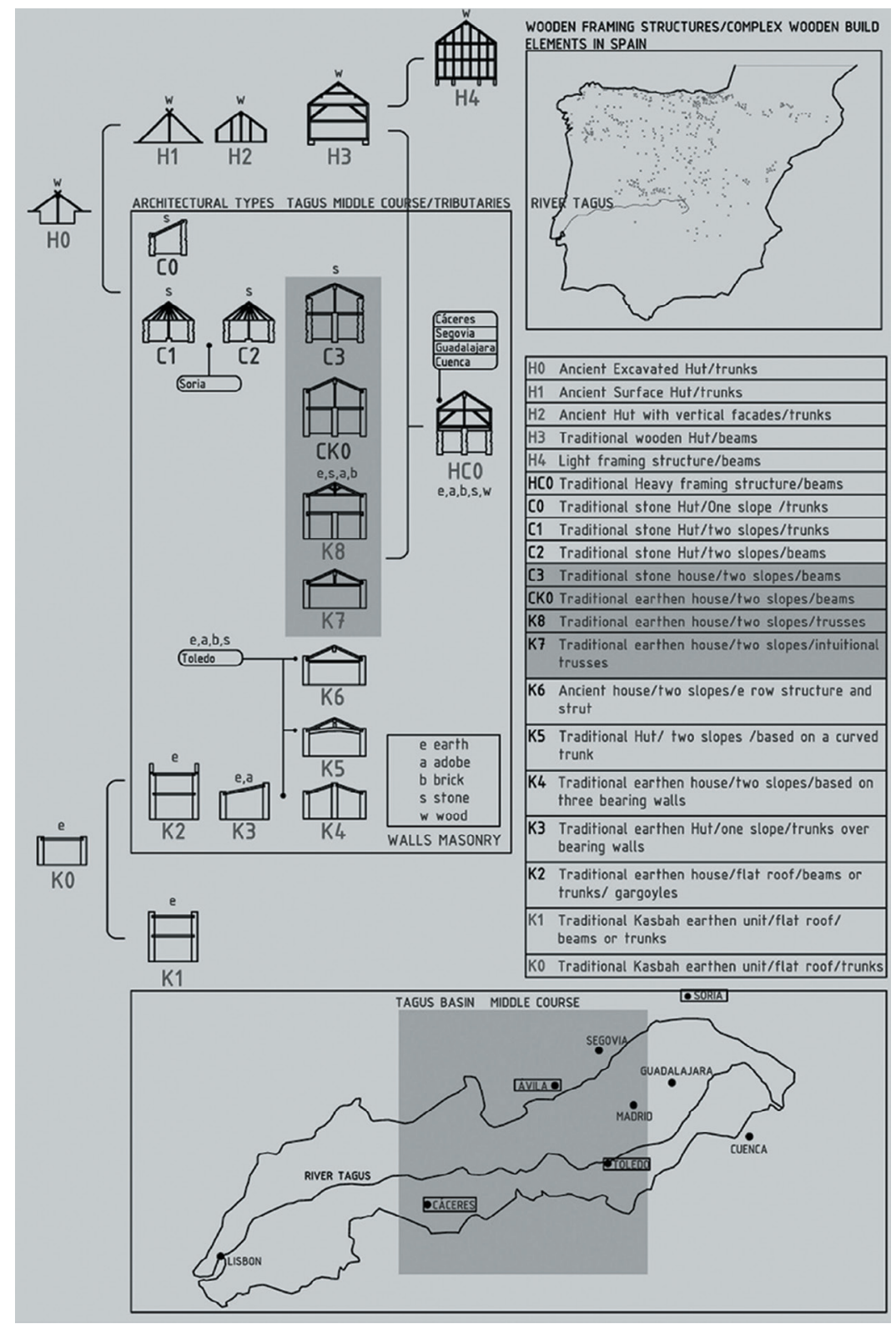

Figuer 2: Evolutions and encounters of Kasbah and hut types. Source: the author. Based on $[10-20,25]$.

Spanish fringe maintains, in many cases, flat roof solutions. The usage of flat roofs diminishes as we reach the first mountain ranges of the Iberian Peninsula.

Vernacular architecture is always in strong relation with the use of land and the natural landscape. Territories in the south of the river Tagus are characterized by agriculture landscapes.

Olive trees, vineyards and cereals are the main civilizations. The predominance of agriculture is a consequence of the existence of several urban concentrations from Roman times that grew intensively during the Islamic conquest. So is the case of Córdoba. 


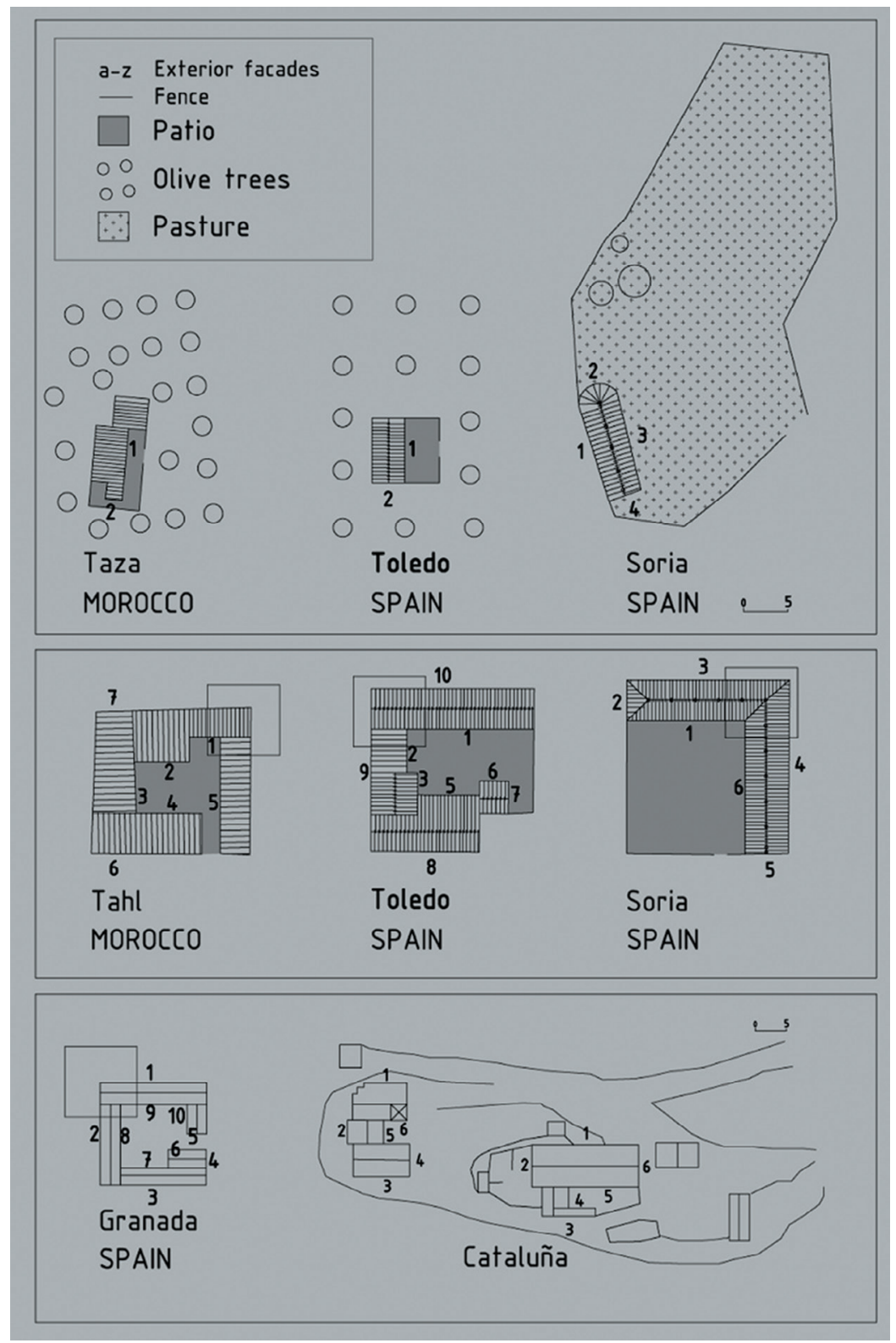

Figure 3: Small- and medium-sized countryside buildings related to farming in Spain and Morocco - Middle Atlas range. Source: the author. Based on [17, 21-23] and the author doctoral Thesis field work.

The Islamic cultural footprint stays clear until we reach the south bank of the river Tagus $[17,24]$. Especially in the isolated architecture related to farming (Fig. 3) and in the smaller urban centres (Fig. 4).

Volumetry [15], the abundance of patio-type distributions [24], the lack and small size of windows, integration of massive staircases [17], pitched roof structural solutions for a maximum of two slopes and the persistent presence of rammed earth bearing walls [3, 25] betray the 


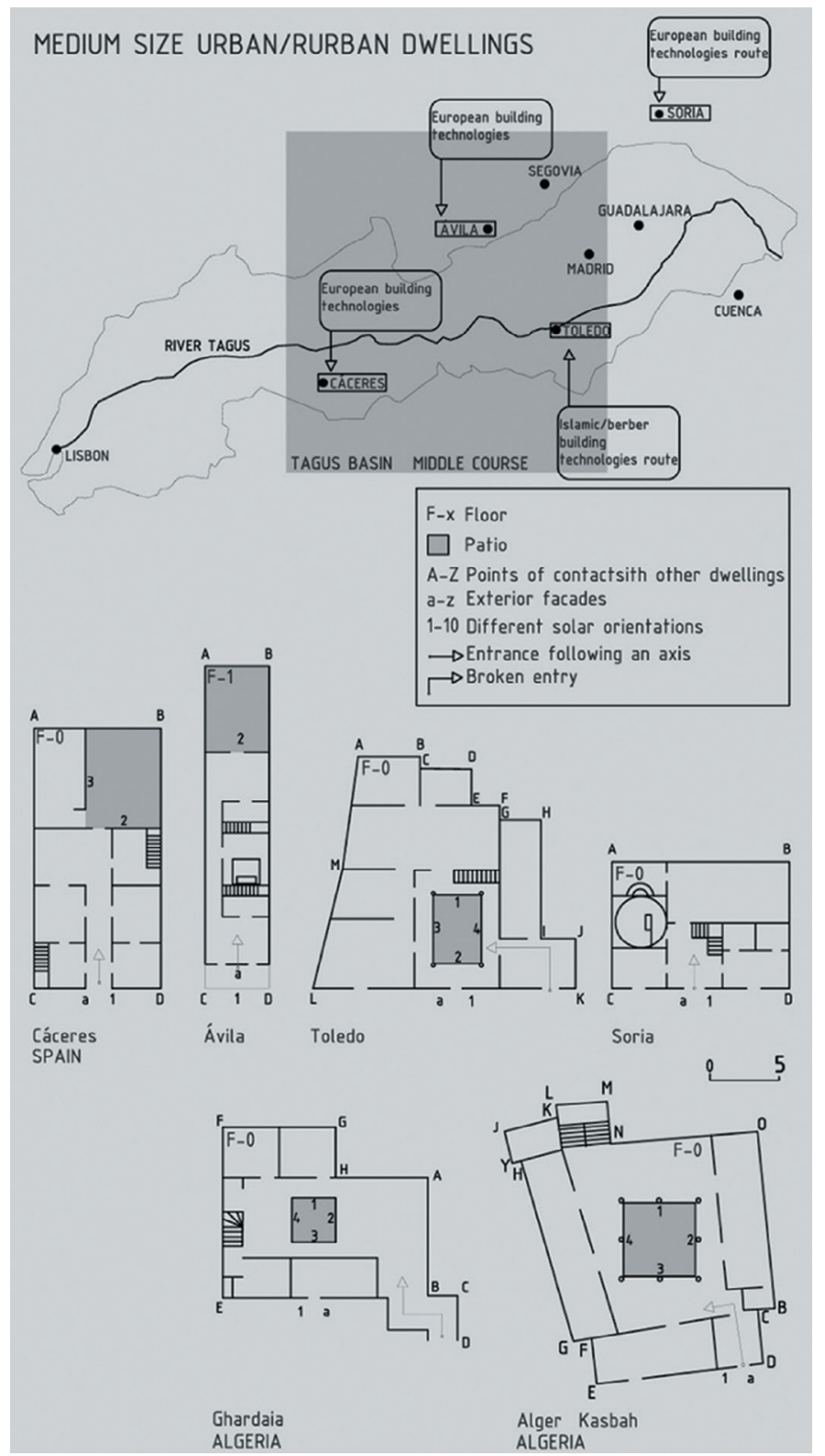

Figure 4: Medium-sized urban/rural dwellings in the Tagus middle course, central Spain and Algeria. Source: the author. Based on $[6,9,15,25]$.

presence of the Kasbah building technologies. Rammed earth walls get reinforced and shaped in their vulnerable points with the materials provided by the land: stone, brick or adobe.

Wood is a scarce resource and it is only used for pitched or horizontal structural purposes. In general, there is no use of wood integrated in walls from the south bank of the river to the south coast of the peninsula in the vertical axis of the Tagus middle course [26]. 


\section{BUILDING TECHNOLOGIES ON THE NORTH SIDE OF THE RIVER TAGUS}

Rammed earth examples can be found in the north of river Tagus. Adobe becomes rife in Castilla y León where earth is the only means for construction. But there is a wooden building technology that appears as we cross the river to the north, which can be found only exceptionally in the southern area: the wooden frame technology [26]. In the north side, wooden framed walls combine with brick or stone in the basement, also with adobe filling the spaces between the wooden parts.

So is the case of Cáceres, Ávila, Salamanca, Segovia, Cuenca [16] and Guadalajara [13, 15] In the south of the province of Soria, wood is used as vertical structure (Fig. 2) in compact buildings with no patio and ground cover, that can reach four slopes even in the poorest cases [21].

In the south of the river, corners between built pieces used to be covered to avoid encounter of more than two slopes [17]. The structural solutions seem to be an intuitive evolution from flat roofs.

In the Portuguese Tagus low course, wooden structures appear with the Avieiro palafitte types, developed strictly on the banks of the river [15].

\section{CONCLUSIONS}

River Tagus has established itself over time as the space of the occidental encounter between rammed earth and wooden construction technologies. A combination of several factors, including historical events and environmental characteristics, has determined its role as a boundary.

Berber and Islamic technologies that entered the Iberian Peninsula during the Islamic conquest are based on compactness, earthen technologies, shared bearing walls, the patiotype and a clear separation from natural environment. Those types and technologies reached Europe through the Iberian Peninsula, mixing with northern solutions in the area of river Tagus and in the south of the central ranges of the peninsula.

European wooden framed technologies with compact volumes, external facades and light structures reached their southernmost border around river Tagus and its tributaries.

The river Tagus has become the place where domestic joint solutions that originated in the Saharan desert meet the architecture born in the green depressions of the greatest European rivers: Lands where wood is lavish and the contact with nature is desirable.

As a result of this encounter, hybrid technologies spread along the northern and southern areas of the river. Mixtures of wood, rammed earth, adobe, brick and stone create a large variety of relationships among architecture, history and the natural landscape.

\section{REFERENCES}

[1] Izquierdo Benito, R, Castilla la Mancha en la Edad Media. Servicio de Publicaciones de la Junta de Comunidades de Castilla la Mancha: Toledo, pp. 5-37, 1985.

[2] Morris, A.E.J., Historia de la forma urbana: desde sus orígenes hasta la revolución industrial, GG: Barcelona, pp. 161, 1984.

[3] Raveréreau, A., Le M'zab: une lecon d'architecture, Sindbad- Actes Sud, París, pp. 59, 64-133, 1984.

[4] Shurtleff, H.R., The Log Cabin Myth: A Study of the Early Dwelling of the English Colonist in North America. Harvard University Press: Cambridge, 1939.

[5] Lima, P. \& Palla, J., Construções palafíticas da bacia do Tejo. Levantamento e diagnóstico do património construido da cultura avieira. ASF: Portugal, 2010.

[6] Meda/Euromed Heritage and Corpus, Arquitectura Tradicional mediterránea, Barcelona, pp. 58-64, 2002. 
[7] Rapoport, A. House, Form and Culture, Prentice Hall, NJ, p. 22, 1969.

[8] Garate, I., Artes de la Cal, Instituto Español de Arquitectura-MRRP y Universidad de Alcalá: Madrid, pp. 180-185, 2002.

[9] Donnadieu, C. \& Didillon, H., Habiter le desert: les maisons mozabites, Architecture et Reserches-Pierre Mardaga: Bruxelles, p. 97, 189-229.

[10] UNESCO World Heritage, available at http://www.palafittes.org/en/pile-dwellings/ index.html (accessed January 2016).

[11] Alcock, N.W., Cruck Construction: An Introduction and Catalogue, The council of British archeology: London, p. 46, 1981.

[12] Rodríguez, M.A., Peraza, F., Peraza, J.E., González, M.A., Arriaga, C. \& Arriaga, F. Casas de madera: los sistemas constructivos a base de madera aplicados a viviendas unifamiliares. AITIM: Madrid, pp. 13-85, 1995.

[13] Berlanga, A., Arquitectura popular y tradicional en el señorío de Molina y Alto Tajo, Diputación de Guadalajara, 2008.

[14] Diderot, D. \& d'Alembert, J.L., Encyclopédie ou dictionnaire raisonné des Sciences, des Arts et des Métiers, París, 1777.

[15] Flores, C. Arquitectura Popular Española, Aguilar: Madrid, Vol. III, p. 303 and Vol. IV, p. $347,1973$.

[16] García Grinda, J.L., Cuadernos de arquitectura de la serranía media conquense. Proder 2- Federación para el desarrollo de la Sierra y Mancha Conquense. Vol. I and II.

[17] Monterrubio, A. Arquitectura Popular de la Jara, Cuarto Centenario: Toledo, p. 91, 2008.

[18] Vellinga, M. Oliver, P. \& Bridge, A., Atlas of Vernacular Architecture of the World, Routledge: Oxon, pp. 24-31, 2007.

[19] "Traditional timber frame roof structures images", http://fet.uwe.ac.uk/conweb/house_ ages/tf2.jpg (accessed January 2016).

[20] "Log cabin in the old European culture characteristics", http://oldeuropeanculture. blogspot.com.es/2015/11/log-cabin.html (accessed January 2016).

[21] Sanz, A., Benito, J.P. \& Tabernero, C., Construcciones con cubierta vegetal en la provincia de Soria. Junta de Castilla y León, 2006.

[22] Feduchi, L., Itinerarios de arquitectura popular española, VIII Los antiguos reinos de las cuatro barras. Ed. Blume, 1976.

[23] Junta de Andalucía, Cortijos, Haciendas y Lagares. Arquitectura de las grandes explotaciones agrícolas de Andalucía. Provincia de Granada. Servicio de Publicaciones, pp. 225, 2009.

[24] García, F.J., Las Ventas: una arquitectura rural singularizada por su función. Las Ventas en la Provincia de Albacete. Colegio Oficial de Arquitectos de Castilla la Mancha: Toledo, pp. 37-49, 2008.

[25] Tahar Bellal, Understanding home cultures through syntactic analysis: The case of Berber housing. Housing, Theory and Society, 21:3, pp. 111-127, 2004.

[26] Nuere, E., La carpintería de armar española, Instituto Español de Arquitectura-MRRP y Universidad de Alcalá: Madrid, pp. 29-100, 2000. 